\title{
Low mitochondrial DNA diversity in the endangered Bonelli's Eagle (Hieraaetus fasciatus) from SW Europe (Iberia) and NW Africa
}

\author{
Luis Cadahía • Juan J. Negro • Vicente Urios
}

\begin{abstract}
This study is an initial survey of the genetic diversity and population structure of the endangered Bonelli's Eagle (Hieraaetus fasciatus) in SW Europe (Iberia) and NW Africa, two locations where the species has undergone a severe decrease in numbers during the last decades. It is also the first study in which the mitochondrial control region (CR) has been used to study the genetic diversity and population structure of this species. Samples were obtained from 72 individuals from Spain, Portugal and Morocco, and a 253bp fragment of the mitochondrial control region was amplified and sequenced. Only three polymorphisms were present, indicating low nucleotide and haplotype diversity. No evidence of genetic structure was found. Several hypotheses may explain these results, including a possible greater genetic diversity in other regions of the mitochondrial genome or the existence of a presumed ancient bottleneck (last glaciation), possibly followed by a human-induced more recent one (twentieth century).
\end{abstract}

Communicated by M. Wink.

L. Cadahía $(\bowtie) \cdot$ V. Urios

Estación Biológica Terra Natura

(Fundación Terra Natura - CIBIO),

Universidad de Alicante, Apdo correos 99, 03080 Alicante, Spain

e-mail: luis.cadahia@gmail.com

J. J. Negro

Departamento de Conservación de la Biodiversidad,

Estación Biológica de Doñana, CSIC,

Avda. de María Luisa, s/n, Pabellón del Perú,

41013 Sevilla, Spain
Keywords Bonelli's eagle · Control region - Genetic diversity · Mitochondrial DNA · Western Palaearctic

\section{Introduction}

Genetic studies of raptors, most of which have involved critically endangered species or populations, have become increasingly important in recent years (Cardia et al. 2002; Godoy et al. 2004; Martínez-Cruz et al. 2004; Roques and Negro 2005). While the debate on the relationship between genetic factors and the conservation of species is ongoing (Amos and Baldford 2001), it is generally accepted that the loss of genetic diversity is not desirable, especially when dealing with endangered taxa, since it reduces the ability of species to cope with environmental changes (Frankham et al. 2002).

The Bonelli's eagle (Hieraaetus fasciatus) is an endangered raptor in Europe (Rocamora 1994). Its major population fractions occur in Southeastern Asia and the western Palaearctic, with some scattered populations in between. In the western Palaearctic it has an irregular distribution range but is mostly restricted to the Mediterranean basin (Cramp and Simmons 1980), with the Iberian Peninsula and Morocco representing the strongholds of this occidental population (Arroyo et al. 1992; Palma et al. 1996). The species has experienced a severe decrease in Spain during the past decades, mainly as a result of powerline accidents and human persecution (Real et al. 2001). Only a few studies on the genetic diversity in Bonelli's eagle are available (Cardia et al. 2000, 2002), and these focus on comparisons of protein genetic variability, the use of inter-simple sequence repeat (ISSR) fingerprints and mitochondrial cytochrome $b$ sequencing. Nevertheless, 
approaches using known non-coding, potentially hypervariable sequences, such as the mitochondrial control region, have not been attempted to date.

Mitochondrial DNA (mtDNA) has been widely utilized as a valuable tool for assessing genetic variation, genetic structure, phylogeographic patterns and phylogeny in different vertebrate groups, including birds (see Avise 2000; Wink 2000). The mitochondrial control region (CR) is referred to as the most variable part of the mitochondrial genome, evolving three- to fivefold faster than the remainder of the mtDNA (Baker and Marshall 1997). As a non-coding region, the CR is not constrained by gene expression limitations, although does contain several short conserved sequence blocks necessary for the replication and transcription of mtDNA (L'Abbé et al. 1991; Clayton 1992). Its basic organization encompasses two flanking highly polymorphic domains (I and III) and a more conserved central one (domain II) (Baker and Marshall 1997).

We present here some preliminary results that constitute an initial assessment of the genetic diversity of Bonelli's eagle based on mitochondrial CR sequences. The potential genetic structure and diversity in populations from part of the western Palaearctic are surveyed by analysing birds from the Iberian Peninsula and NW Africa.

\section{Methods}

Samples

A total of 72 samples were analysed. Of these, 51 originated from different areas of the species' range in Spain, 13 were from Portugal and eight from Morocco (Fig. 1). Samples were selected to represent all of the areas where Bonelli's eagle occurs in a balanced distribution, and they were assigned a priori to five different regions according to geographical origin, which were considered to represent different sub-populations (Fig. 1). All of the samples except one - a body feather - consisted of blood preserved in 70\% ethanol (41 samples) or Seutin's buffer (19 samples; Seutin et al. 1991) or blood cells frozen after centrifugation and plasma separation (11 samples).

\section{DNA extraction and purification}

Genomic DNA was extracted following the proteinase $\mathrm{K}-\mathrm{LiCl}$ method (Gemmel and Akiyama 1996). Depending on the material, either $100 \mu \mathrm{l}$ (in the case of the ethanol and Seutin samples), a sample of the frozen blood cells or the calamus of the body feather were incubated at $56^{\circ} \mathrm{C}$ overnight in extraction buffer (100 $\mathrm{m} M \mathrm{NaCl}, 50 \mathrm{~m} M$ Tris- $\mathrm{HCl}, 1 \%$ sodium dodecyl sulfate, $50 \mathrm{~m} M$ EDTA, $\mathrm{pH} 8 ; 100 \mu \mathrm{g} / \mathrm{ml}$ proteinase $\mathrm{K}$ ). Nucleic acids were first extracted with $5 \mathrm{M} \mathrm{LiCl}$ and chloroform:isoamyl alcohol (24:1) and then precipitated with ethanol.

PCR amplification and sequencing

A fragment of approximately $253 \mathrm{bp}$ encompassing a part of the domain I of the CR was used as a marker sequence. This fragment has been successfully used as a molecular marker in previous studies with other raptor species, since it has been shown to contain most of the polymorphic sites (Gypaetus barbatus, Godoy et al. 2004; Aquila adalberti, Martínez-Cruz et al. 2004). The primers used bind in the threonine tRNA gene and in a conserved sequence block (Fbox), respectively: $T h r$-F (5'-TTGGTCTTGTAAACCAAARAN TGAAG-3'), Fbox -R (5'-GGGTTGCTGRTTTCACG TGAG-3') (Godoy et al. 2004).

Amplification was performed in $20-\mu$ l volumes containing $1 \times$ PCR buffer, $2.5 \mathrm{mM} \mathrm{MgCl}$, $1 \mathrm{U}$ Taq polymerase (Biotaq DNA Polymerase kit; Bioline, Turin, Italy), $0.2 \mathrm{~m} M$ of each nucleotide and $1 \mu M$ of each primer. The PCR reaction was carried out in a PTC100 (MJ Research, Waltham, Mass.) thermocycler set at the following amplification parameters: an initial 2 min heating at $94^{\circ} \mathrm{C}$, followed by 34 cycles of $92^{\circ} \mathrm{C}$ for $30 \mathrm{~s}$ (denaturation), $64^{\circ} \mathrm{C}$ for $30 \mathrm{~s}$ (annealing) and $72^{\circ} \mathrm{C}$ for $30 \mathrm{~s}$ (elongation) and terminated with $5 \mathrm{~min}$ at $72^{\circ} \mathrm{C}$. Amplified PCR products were purified using Millipore (Microcon-Genomics) purification columns and TE buffer, $\mathrm{pH}$ 8, and sequenced in an ABI Prism 3100 sequencer (PE Biosystems, Foster City, Calif.).

Sequence analysis

Sequences were aligned in Clustal W ver. 1.82 (Thompson et al. 1994) using default parameters. The JALVIEW alignment editor (Clamp et al. 2004) was used to edit the sequences manually. A subsequent ends-cut was performed as the quality at the sequence extremes was very low in most cases. Comparisons were applied to analyse the divergence among sequences using $P$ distances in MEGA ver. 2.1 (Kumar et al. 2001) and a similarity table in PHYLIP ver. 3.6b (DNADIST) (Felsenstein 2004). Nucleotide diversity was calculated in MEGA ver. 2.1 and haplotype diversity in DnaSP ver. 4.0 (Rozas and Rozas 1999). The possible existence of population genetic structure in the five subpopulations defined a priori was explored by means of an analysis of molecular variance (AMOVA) (Excof- 




Fig. 1 Geographical distribution of the samples used to study the genetic diversity in Bonelli's eagle (Hieraaetus fasciatus) in the western Palaearctic. Letters represent populations defined a priori. NE Northeastern Iberian Peninsula, $S E$ southeastern Iberian Peninsula, $S W$ southwestern Iberian Peninsula, $C$ Central Iberian Peninsula, $N W$ Af northwestern Africa. Numbers of samples taken are indicated (in the SW and C areas, samples from Spain and Portugal are specified separately)

fier et al. 1992) using $\Phi$ estimators (Wright 1965) as implemented in ARLEQUiN (Schneider et al. 2000), considering both the haplotype frequencies and the molecular distance (Tamura and Nei 1993) among haplotypes.

\section{Results}

Analysis of the sequences of the 72 samples revealed only three polymorphisms (positions 48, 165 and 208), all of which were A-G transitions, resulting in four haplotypes. One haplotype was only present in a single individual from Morocco (Table 1). Thus, the relative proportion of segregating sites $(\mathrm{S} / \mathrm{L})$ was 0.0119 . Mean nucleotide diversity $(\pi)$ (Nei and $\mathrm{Li}$ 1979) was
$0.0024 \pm 0.0017$ (the standard error was estimated by 1000 bootstrap replicates), haplotype diversity was $0.542 \pm 0.046( \pm \mathrm{SD})$ and the percentage of divergence between sequences was below $1 \%$ (range: $0-0.79 \%$ ).

The analysis of molecular variance revealed low, non-significant $\Phi_{\mathrm{ST}}$ values using both haplotype frequencies $\left(\Phi_{\mathrm{ST}}=-0.02622\right)$ and Tamura-Nei molecular distances $\left(\Phi_{\mathrm{ST}}=0.00423\right)$, with less than $1 \%$ of the observed variation partitioned among sub-populations. Thus, most of the variation was found to occur within sub-populations and no genetic structure was recognized (Fig. 2).

\section{Discussion}

The western population of Bonelli's eagle exhibits a low degree of genetic diversity at the mtCR level. This is reflected both by the small number of polymorphisms found as well as by the fact that all of the polymorphisms consisted of transitions, which are far more frequent than transversions within the animal mitochondrial genome (transition/transversion ratio ranges from 15 to 20; Graur and Li 2000).

This result agrees with that of a previous study on the species involving sequencing of the mitochondrial cytochrome $b$ gene and analyses of ISSR markers and protein variation (Cardia et al. 2000). Cytochrome $b$ is a leisurely evolving gene that is often used for revealing species' relationships, although it may also be helpful for exploring broad phylogeographic patterns (Avise 2000). The conclusions arrived at by Cardia et al. (2000) based on an analysis of cytochrome $b$ might have been influenced by methodological biases, especially regarding the resolution capacity of the selected marker. Nonetheless, our results are consistent with those of these researchers and show, for example, an analogous percentage of sequence divergence $(<1 \%)$ within cytochrome $b$ and $\mathrm{CR}$ sequences, even though the latter is assumed to evolve more rapidly. Other studies using a higher number of protein loci

Table 1 Haplotypic variants in a 253-bp fragment of the mitochondrial control region (CR) in 72 Bonelli's eagles from Morocco, Portugal and Spain

\begin{tabular}{|c|c|c|c|c|c|c|c|c|c|}
\hline \multirow[t]{2}{*}{ Haplotype } & \multicolumn{3}{|c|}{ Position (in bp) } & \multicolumn{6}{|c|}{ Samples (frequencies) ${ }^{\mathrm{a}}$} \\
\hline & 48 & 165 & 208 & $\mathrm{C}$ & $\mathrm{NE}$ & SE & SW & NW Af & TOT \\
\hline HapA & G & G & G & $2(0.661)$ & $7(0.636)$ & $10(0.556)$ & $21(0.656)$ & $4(0.500)$ & $44(0.611)$ \\
\hline НарВ & A & - & - & $1(0.339)$ & $2(0.182)$ & $8(0.444)$ & 7 (0.219) & $3(0.375)$ & $21(0.292)$ \\
\hline НарC & - & - & A & - & $2(0.182)$ & - & $4(0.125)$ & - & $6(0.083)$ \\
\hline HapD & - & A & - & - & - & - & - & $1(0.125)$ & $1(0.014)$ \\
\hline
\end{tabular}

${ }^{a}$ C, Central Iberian Peninsula; NE, northeastern Iberian Peninsula; SE, southeastern Iberian Peninsula; SW southwestern Iberian Peninsula; NW Af northwestern Africa 
Fig. 2 Network of the four mitochondrial CR haplotypes present in Bonelli's eagle's (H. fasciatus) western Palaearctic population, showing the relationship between these and the geographical origin of the individuals studied

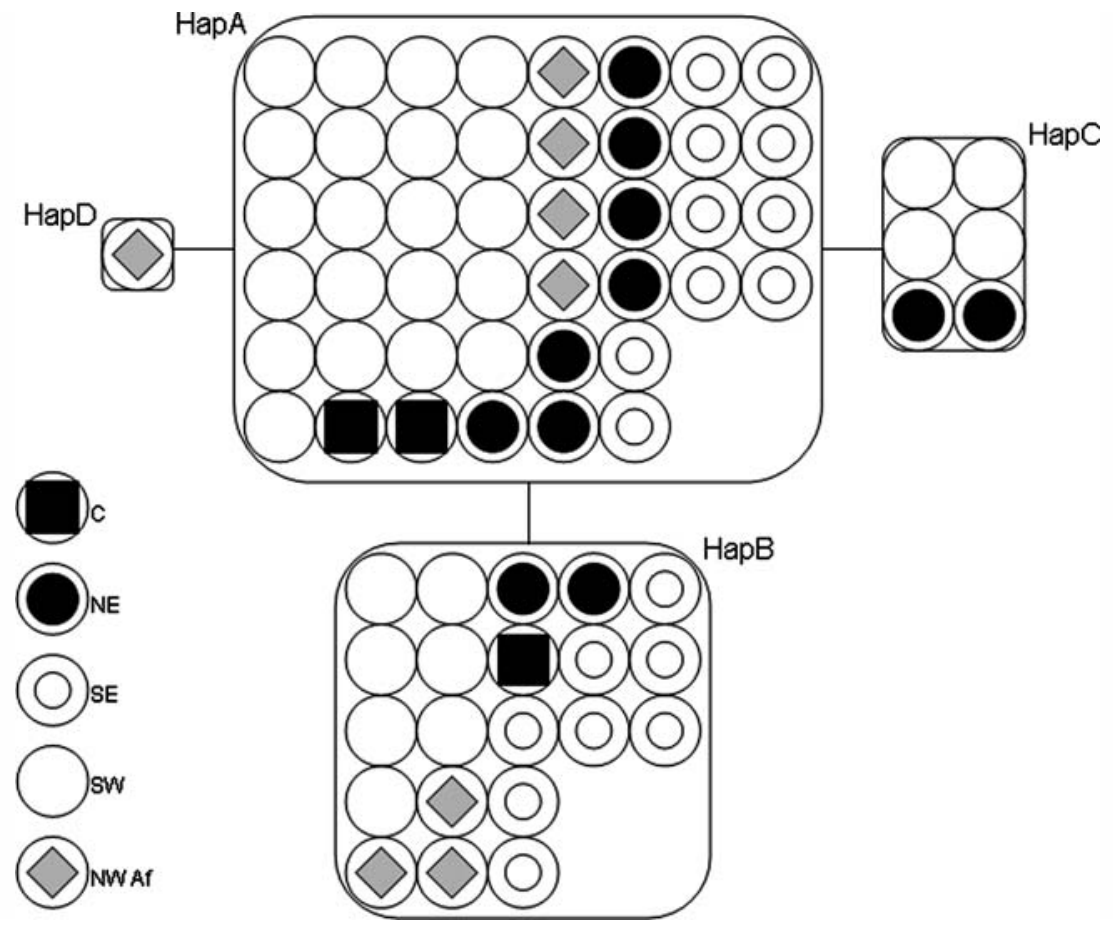

revealed greater genetic diversity than what we obtained here (Cardia et al. 2002).

A similar low level of genetic variation has also been reported in some other large raptor species, such as the Spanish imperial eagle (Aquila adalberti) (MartínezCruz et al. 2004). Other related taxa exhibit somewhat higher levels of nucleotide and haplotype diversities, including the imperial eagle Aquila heliaca (MartínezCruz et al. 2004), the red kite (Milvus milvus) (Roques and Negro 2005) and the bearded vulture (Gypaetus barbatus) (Godoy et al. 2004) (Table 2). In most of these surveys mtDNA sequencing, particularly sequencing of the CR, was the chosen approach. However, it seems that results based on the CR must be taken with caution, since it has been demonstrated that the $\mathrm{CR}$ is not always the most variable region within the mitochondrial genome, at least in some avian species (Ruokonen and Kvist 2002). That is the case in buzzards Buteo spp., where a second highly variable non-coding region, designated the pseudocontrol region by Haring et al. (1999), has been found to contain a greater genetic diversity than the CR (Kruckenhauser et al. 2004). This region has also been found in other bird species (see Bensch and Härlid 2000; Eberhard et al. 2001) and it has been successfully used in some molecular studies on raptors (Väli 2002; Riesing et al. 2003). Within this context, our results could be explained by the fact that the CR of Bonelli's eagle - or at least the fragment we have analysed - is not as variable as in other raptors studied to date. Additionally, another hypothesis that might explain the population's low genetic diversity proposes the existence of one or more possible bottlenecks, either an ancient one during the last glaciation or a humaninduced one which would have taken place in the recent past (twentieth century).

With respect to genetic structure, the fact that the least frequent haplotype was found in a single individ-

Table 2 Mitochondrial control region diversity in Bonelli's eagle and other raptor species

\begin{tabular}{llllclc}
\hline Species $^{\mathrm{a}}$ & $n^{\mathrm{b}}$ & $\begin{array}{l}\text { Number of } \\
\text { haplotypes }\end{array}$ & $\begin{array}{l}\text { Number of } \\
\text { polymorphic sites }\end{array}$ & Haplotype diversity & $\begin{array}{l}\text { Nucleotide } \\
\text { diversity }\end{array}$ & $\begin{array}{l}\text { Average no. of } \\
\text { pairwise differences }\end{array}$ \\
\hline Hieraaetus fasciatus & 72 & 4 & 3 & $0.5420 \pm 0.0460$ & $0.00238 \pm 0.00170$ & $0.602 \pm 0.2350$ \\
Aquila adalberti & 60 & 3 & 2 & $0.3215 \pm 0.0730$ & $0.00098 \pm 0.00024$ & $0.338 \pm 0.0632$ \\
Aquila heliaca & 34 & 7 & 8 & $0.7790 \pm 0.0420$ & $0.00548 \pm 0.00068$ & $1.891 \pm 0.2665$ \\
Milvus milvus & 105 & 10 & 10 & 0.6100 & 0.0032 & - \\
Gypaetus barbatus & 172 & 50 & 28 & $0.9320 \pm 0.0120$ & $0.02920 \pm 0.01530$ & $6.650 \pm 3.1600$ \\
\hline
\end{tabular}

${ }^{a}$ Sources: A. aldalberti and A. heliaca, Martínez-Cruz et al. 2004; G. barbatus, Godoy et al. 2004; M. milvus, Roques and Negro 2005

b $n$, Number of samples 
ual coming from Morocco may reflect some geographical pattern. However the remaining haplotypes did not show any geographical distribution. Cardia et al. (2000) found a slight difference between eastern and western Mediterranean Bonelli's populations as well as a possible $\mathrm{N}-\mathrm{S}$ gradient in one protein locus within Portugal, although the remaining loci they studied did not differ among populations. This result, along with the low diversity and the lack of genetic structure we found, does not provide any evidence for a restriction of gene flow in the western part of the Mediterranean basin. Evidence supporting a more or less panmictic population on the Iberian Peninsula comes from several studies which demonstrate that Bonelli's juveniles travel long distances from their natal places to a few settlement areas (Arroyo et al. 1992; Real and Mañosa 2001; Cadahía et al. 2005). One hypothesis - that this may increase their chance of meeting potential mates coming from other regions of the species' range - is supported by two pieces of evidence. First, genetic data indicating the possibility of a Spanish bird breeding in SW Portugal have been presented (Cardia et al. 2002). In addition, the case of one bird born in southern Spain (Andalusia) and found breeding approximately $700 \mathrm{~km}$ away, in northern Spain (La Rioja) several years later (J. Balbontín, personal communication) has also been reported recently.

Our results show very little genetic diversity in a fragment of domain I of the mtCR in Bonelli's eagle. Future investigations should include an increased sample size, especially from the African area, a study of the remainder of the mtCR as well as other potentially hyper-variable non-coding regions of the $\mathrm{mt}$ genome, such as the pseudo-CR (Haring et al. 1999), and the analysis of museum samples dating from several decades ago to explore the possibility of a recent bottleneck. Such studies will facilitate the testing of the hypotheses presented here and help us gain a better understanding of the population genetics of Bonelli's eagle as well as make an assessment of the impact of the human activities on this species' genetic diversity in SW Europe and NW Africa.

\section{Zusammenfassung}

Geringe Diversität der mitochondrialen DNA in bedrohten Habichtsadlern (Hieraaetus fasciatus) in Südwest-Europa (Iberische Halbinsel) und Nordwest-Afrika

Diese vorläufige Studie beschreibt die genetische Diversität und Populationsstruktur von Habichtsadl- ernb (Hieraaetus fasciatus) aus Südwest-Europa (Iberische Halbinsel) and Nordwest-Afrika, wo diese bedrohte Art während der letzten Jahrzehnte einen drastischen Rückgang erfahren hat. Als genetischer Marker wurde die mitochondriale Kontrollregion (CR) eingesetzt. Von 72 Vögeln aus Spanien, Portugal und Marokko wurden Proben genommen und ein $253 \mathrm{bp}$ langes Stück der CR amplifiziert und sequenziert. Die gefundene Nukleotid- und Haplotypendiversität in den untersuchten Individuen war sehr gering. Es wurden in diesem DNA-Abschnitt nur drei polymorphe Positionen gefunden. Weiterhin wurde keinerlei populationsgenetische Struktur gefunden, da die Verbreitung der Haplotypen kein geografisches Muster aufweist. Ein genetischer „Flaschenhals” während der letzten Eiszeit, eventuell gefolgt von einem (möglicherweise mehreren) weiteren, durch Menschen induzierten (zum Beispiel im letzten Jahrhundert) bietet sich als Erklärung an. Weitere Abschnitte des mitochondrialen Genoms sollten auf ihre genetische Variabilität untersucht werden, um festzustellen, ob sie als populationsgenetische Marker besser geeignet sind.

Acknowledgements We are indebted to all of the people and organizations that provided samples for the present study: J. Balbontín (Estación Biológica de Doñana), S. Mira (University of Algarve), C. Gerique (C.R.F. El Saler), A. García (GREFA), I. Molina (EGMASA), M.R. Jané (ICRA) and A. Gardiazábal. We are also grateful to the Governments of the Comunidad Valenciana, Catalunya and Región de Murcia, the Universities of Barcelona and Miguel Hernández and the Spanish Ministerio de Medio Ambiente (especially V. García Matarranz) for giving permission to have access to nests and for invaluable field assistance. We appreciatively acknowledge J. Muñoz for his help in the laboratory as well as all of the other people working in the Laboratory of Molecular Ecology of the Estación Biológica de Doñana. We are grateful to $S$. Roques for her help with the software. E. Haring, A. Juan, R. Limiñana, E. Micó, A. Soutullo and two anonymous referees provided critical reading and very valuable comments on early versions of the manuscript. This project was funded by the Terra Natura Foundation. L. Cadahía is supported by a grant of the Spanish Ministerio de Educación y Ciencia (reference AP2001-1444). This paper is part of L. Cadahía's PhD thesis at the University of Alicante.

\section{References}

Amos W, Balmford A (2001) When does conservation genetics matter? Heredity 87:257-265

Arroyo B, Ferreiro E, Garza V (1992) Factores limitantes de la población de águila perdicera en España. Technical report ICONA (Ministerio de Medio Ambiente), Madrid

Avise JC (2000) Phylogeography: the history and formation of species. Harvard University Press, Cambridge

Baker AJ, Marshall HD (1997) Mitochondrial control region sequences as tools for understanding evolution. In: Mindell DP (ed) Avian molecular evolution and systematics. Academic Press, London, pp 51-82 
Bensch S, Härlid A (2000) Mitochondrial genomic rearrangements in songbirds. Mol Biol Evol 17:107-113

Cadahía L, Urios V, Negro JJ (2005) Survival and movements of satellite tracked Bonelli's eagles during their first winter. Ibis 147:415-419

Cardia P, Fraguas B, Pais M, Guillemaud T, Palma L, Cancela ML, Ferrand N, Wink M (2000) Preliminary genetic analysis of some western Palaearctic populations of Bonelli's eagle, Hieraaetus fasciatus. In: Chancellor RD, Meyburg B-U (eds) Raptors at risk. WWGBP/Hancock House, London

Cardia P, Fraguas B, Pais M, Silva S, Guillemaud T, Palma L, Cancela ML, Ferrand N (2002) Análise da variação genética de proteínas em populações mediterrânicas de águia-perdigueira Hieraaetus fasciatus. Airo 12:71-74

Clamp M, Cuff J, Searle SM, Barton GJ (2004) The JALview Java alignment editor. Bioinformatics 20:426-427

Clayton DA (1992) Transcription and replication of animal mitochondrial DNAs. In: Wolstenholme DR, Jeon KW (eds) Mitochondrial genomes International review of cytology, vol 141. Academic Press, San Diego, pp 217-232

Cramp S, Simmons KEL (1980) Handbook of the birds of Europe, the Middle East and North Africa, vol 2. Oxford University Press, Oxford

Eberhard JR, Wright TF, Bermingham E (2001) Duplication and concerted evolution of the mitochondrial control region in the parrot genus Amazona. Mol Biol Evol 18:1330-1342

Excoffier L, Smouse PE, Quattro JM (1992) Analysis of molecular variance inferred from metric distances among DNA haplotypes: application to human mitochondrial DNA restriction data. Genetics 131:479-491

Felsenstein J (2004) PHYLIP (Phylogeny Inference Package), version 3.6. Distributed by the author. Department of Genome Sciences, University of Washington, Seattle

Frankham R, Ballou BD, Briscoe DA (2002) Introduction to conservation genetics. Cambridge University Press, Cambridge

Gemmell N, Akiyama S (1996) An efficient method for the extraction of DNA from vertebrate tissue. Trends Genet $12: 338-339$

Godoy JA, Negro JJ, Hiraldo F, Donázar JA (2004) Phylogeography, genetic structure and diversity in the endangered bearded vulture (Gypaetus barbatus L.) as revealed by mitochondrial DNA. Mol Ecol 13:371-390

Graur D, Li W-H (2000) Fundamentals of molecular evolution, 2nd edn. Sinauer Assoc, Sunderland

Haring E, Riesing MJ, Pinkser W, Gamauf A (1999) Evolution of a pseudo-control region in the mitochondrial genome of Palearctic buzzards (genus Buteo). J Zool Syst Evol Res 37:185-194

Kruckenhauser L, Haring E, Pinsker W, Riesing MJ, Winkler H, Wink M, Gamauf A (2004) Genetic vs. morphological differentiation of Old World buzzards (genus Buteo, Accipitridae). Zool Scripta 33:197-211

Kumar S, Tamura K, Jakobsen IB, Nei M (2001) MEGA2: molecular evolutionary genetics analysis software. Bioinformatics 17:1244-1245
L'Abbé D, Duhaime JF, Lang BF, Morais R (1991) The transcription of DNA in chicken mitochondria initiates from one major bidirectional promoter. J Biol Chem 266:10844-10850

Martínez-Cruz B, Godoy JA, Negro JJ (2004) Population genetics after fragmentation: the case of the endangered Spanish imperial eagle (Aquila adalberti). Mol Ecol 13:2243-2255

Nei M, Li W (1979) Mathematical model for studying genetic variation in terms of restriction endonucleases. Proc Natl Acad Sci USA 76:5269-5273

Palma L, Pais MC, Fráguas B (1996) Status and distribution of Bonelli's eagle, Hieraaetus fasciatus, in Portugal. In: II Int Conf Raptors. Urbino, Italy

Real J, Mañosa S (2001) Dispersal of juvenile and immature Bonelli's eagles in Northeastern Spain. J Raptor Res 35:9-14

Real J, Grande JM, Mañosa S, Sánchez-Zapata JA (2001) Geographic variation of the causes of death of Bonelli's eagle Hieraaetus fasciatus in Spain. Bird Study 48:221-228

Riesing MJ, Kruckenhauser L, Gamauf A, Haring E (2003) Molecular phylogeny of the genus Buteo based on mitochondrial maker sequences. Mol Phyl Evol 27:328-342

Rocamora G (1994) Bonelli's eagle Hieraaetus fasciatus. In: Tucker GM, Heath MF (eds) Birds in Europe: their conservation status. Birdlife International, Cambridge, pp 184-185

Roques S, Negro JJ (2005) MtDNA genetic diversity and population history of a dwindling raptorial bird, the red kite (Milvus milvus). Biol Conserv 126:41-50

Rozas J, Rozas R (1999) DnaSP version 3: an integrated program for molecular population genetics and molecular evolution analysis. Bioinformatics 15:174-175

Ruokonen M, Kvist L (2002) Structure and evolution of the avian mitochondrial control region. Mol Phylogenet Evol 23:422-432

Schneider S, Roessli D, Excoffier L (2000) ArLEQuin ver. 2.000: software for population genetics data analysis. Genetics and Biometry Laboratory, University of Geneva, Switzerland

Seutin G, White BN, Boag PT (1991) Preservation of avian blood and tissue samples for DNA analyses. Can J Zool 69:82-90

Tamura K, Nei M (1993) Estimation of the number of nucleotide substitutions in the control region of mitochondrial DNA in humans and chimpanzees. Mol Biol Evol 10:512-526

Thompson JD, Higgins DG, Gibson TJ (1994) CLUSTAL W: improving the sensitivity of progressive multiple sequence alignment through sequence weighting, position-specific gap penalties and weight matrix choice. Nucleic Acids Res 22:4673-4680

Väli Ü (2002) Mitochondrial pseudo-control region in old world eagles (genus Aquila). Mol Ecol 11:2189-2194

Wink M (2000) Advances in DNA studies of diurnal and nocturnal raptors. In: Chancellor RD, Meyburg B-U (eds) Raptors at risk. WWGBP, Hancock House

Wright S (1965) The interpretation of population structure by Fstatistics with special regard to systems of mating. Evolution 19:395-420 